\title{
A high-performance, bifunctional oxygen electrode catalysed with palladium and nickel-iron hexacyanoferrate
}

\author{
R.D. $M^{c}$ Kerracher ${ }^{a}$, H.A. Figueredo-Rodríguez, ${ }^{a}$ C. Ponce de León ${ }^{a}{ }^{*}$, C. Alegre ${ }^{b}$, V. Baglio \\ ${ }^{\mathrm{b}}$, A.S. Aricò ${ }^{\mathrm{b}}$, F.C. Walsh ${ }^{\mathrm{a}}$ \\ ${ }^{a}$ Electrochemical Engineering Laboratory, Engineering Sciences, Faculty of Engineering and \\ the Environment, University of Southampton, Highfield, Southampton, SO17 1BJ, UK \\ ${ }^{\text {b}}$ Consiglio Nazionale delle Ricerche, Istituto di Tecnologie Avanzate per l'Energia " Nicola \\ Giordano", Salita S.Lucia sopra Contesse, 5. 98126 Messina, Italy
}

\begin{abstract}
The development of air-breathing cathodes, which utilise atmospheric oxygen, enables the construction of lightweight, high energy density metal-air batteries and fuel cells. Air electrodes can be very lightweight and thin because the active material, oxygen, does not need to be stored inside the cell. However, air electrodes are restricted by poor reaction kinetics and low activity of many catalysts towards the oxygen evolution and reduction reactions. In addition, it is a challenge to maintain chemical and mechanical stability of the catalyst and supporting materials at oxidising currents under the strong alkaline conditions commonly used, and gas evolution. This paper reports a novel bifunctional oxygen electrode with remarkable stability, able to perform at current densities up to $1,000 \mathrm{~mA} \mathrm{~cm}^{-2}$ and withstand 3,000 cycles continuously. The electrode is catalysed by a mixture of $\mathrm{Pd} / \mathrm{C}$ and mixed nickel-iron hexocyanoferrate, which have high activities towards the ORR and OER reactions, respectively.
\end{abstract}

Key words: air cathode; bifunctional electrode; metal air batteries; nickel-iron; palladium. 


\section{Introduction}

Metal/air batteries (MABs) use oxygen from the atmosphere, in contrast to traditional batteries where the reagents are contained within the cell. Several systems for fundamental studies or as prototypes exist but only few have reached commercial stage. Typical MABs include $\mathrm{Zn} / \mathrm{O}_{2},[1]$ $\mathrm{Li} / \mathrm{O}_{2},[2] \mathrm{Na} / \mathrm{O}_{2},[3] \mathrm{K} / \mathrm{O}_{2},[4] \mathrm{Mg} / \mathrm{O}_{2},[5] \mathrm{Ca} / \mathrm{O}_{2},[6] \mathrm{Al} / \mathrm{O}_{2},[7] \mathrm{Si} / \mathrm{O}_{2},[8]$ and $\mathrm{Fe} / \mathrm{O}_{2}$ [9]. In nonaqueous systems during the discharge cycle, the metal oxidises and its ions migrate through the electrolyte to the gas diffusion electrode (GDE) where they form a solid oxide with the reduced oxygen. Similar processes occur in aqueous systems, in some cases, the oxide forms on the metal electrode such as in the iron-air battery, where the formation of the solids $\mathrm{Fe}(\mathrm{OH})_{2}$ and $\mathrm{Fe}_{3} \mathrm{O}_{4}$ occurs [10]. In other cases such as in the zinc-air battery, zincate ion $\mathrm{Zn}(\mathrm{OH})_{4}^{-}$ions dissolve in the strong alkaline electrolyte. In non-rechargeable batteries, the metal oxide is stable and the capacity of the battery depends on the amount of metal; the battery is recycled once the metal is consumed. Recently, there has been an increased interest in rechargeable metal-air batteries. In non-aqueous systems, the battery is recharged by electrodeposition of metal at the negative electrode together with the oxygen evolution from the oxide decomposition at the positive electrode, while in aqueous systems, the battery is charged by the electrodeposition of metal at the negative electrode together with oxygen evolution reaction (OER) via the oxidation of water, at the positive electrode.

In aqueous systems the oxygen reduction reaction (ORR) and the oxygen evolution reaction (OER) occur on the same electrode during the discharge and charge cycles, respectively. This requires a special bifunctional catalyst. Ideally, this catalyst should be able to facilitate both reactions close to the equilibrium potential. One of the main challenges of designing a bifunctional oxygen electrode is producing an electrochemically stable catalyst which is highly 
active towards both the ORR and OER, and is supported within a stable high surface area catalyst layer. Carbon is a popular choice for a catalyst support but it has proven a challenge to maintain its mechanical and electrochemical stability during repeated charge-discharge cycles $[11,12]$. Therefore, even if the catalyst is highly effective, the catalyst layer of the electrode may degrade or disintegrate during oxygen evolution. This can be minimised by using highly graphitised carbons that are more corrosion resistant. Since the oxygen reduction and evolution reactions occur at the point of contact between the electrolyte and the catalyst, the catalyst support requires a highly porous structure in order to allow the oxygen gas to enter and exit the structure easily. It is also desirable that the morphology of the electrode surface is designed in such a way that facilitates the rapid formation and removal of the gas bubbles. However, a compromise should be made to provide the highly porous structure required with the mechanical stability of the electrode.

Commercially available oxygen electrodes have various geometrical characteristics: electrodes that favour the OER allow the oxygen bubbles to escape through open structures such as open meshes or tilted structures. Electrodes for the ORR use highly porous surface structures (35\% $-65 \%$ ) rigid carbon supports and a gas diffusion layer (GDL) with modulated porosity (100300 microns) with the catalytic layer on top (2-1000 nm thickness). Since the two oxygen reactions require different electrode characteristics, a compromise between structure types is required to maximise the bifunctional activity and stability of the catalyst. The electrode should facilitate the release of oxygen generated during the charge cycle whilst allowing oxygen from the air to enter during the discharge cycle. While most laboratory studies use pure oxygen to evaluate the electrodes, metal-air batteries should be able to work with atmospheric air which will require a larger flow rate to compensate for the ca. $21 \%$ oxygen content of air. Experiments with oxygen help to determine the catalyst activity but might mask the true effects 
of mass transport when air is used. In this paper, pure oxygen was used to evaluate the catalytic activity of the electrodes, in order that the results are standardised (the oxygen content of air will vary in different laboratories; whereas pure oxygen from a cylinder is always $100 \%$ oxygen).

Typical bifunctional catalysts used in oxygen electrodes include platinum [13] palladium [9] and non-noble metal compound phases, such as perovskites, [14] spinels, [15, 16] and pyrochlores [17]. Perovskite catalysts mixed with high surface area carbon are some of the most promising bifunctional catalyst materials produced to date but reported data varies depending on the type of perovskite and operational conditions. Velraj et al. [18] reported that the performance of electrodes prepared with perovskite catalyst $\left(\mathrm{La} 0.6 \mathrm{Ca} 0.4 \mathrm{CoO}_{3}\right.$ or $\left.\mathrm{Sr}_{0.5} \mathrm{Sm}_{0.5} \mathrm{CoO}_{3-\delta}\right)$ with different Vulcan XC-72R carbon black at $\pm 50 \mathrm{~mA} \mathrm{~cm}{ }^{-2}(\mathrm{OER}$ and ORR at $+0.65 \mathrm{~V}$ and $-0.2 \mathrm{~V}$ vs. $\mathrm{Hg} / \mathrm{HgO}$, respectively) in $8.5 \mathrm{~mol} \mathrm{dm}^{-3} \mathrm{KOH}$, was limited to $100-110$ cycles due to degradation of the carbon support. The catalyst maintained its catalytic activity and the authors suggested that alternative non-carbon supports need to be developed, such as $\mathrm{Nb}$-doped $\mathrm{TiO}_{2}$ nanoparticles [19] or Ebonex [20]. Gas diffusion electrodes manufactured with perovskite catalysts of type $\mathrm{La} 0.6 \mathrm{Ca} 0.4 \mathrm{Co} 0.8 \mathrm{~B}_{0.2} \mathrm{O}_{3}(\mathrm{~B}=\mathrm{Mn}, \mathrm{Fe}, \mathrm{Co}, \mathrm{Ni}, \mathrm{Cu})$ developed by

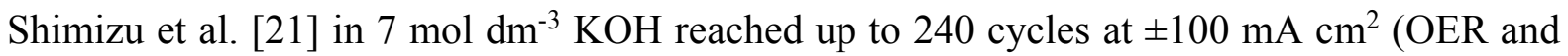
ORR at $+0.6 \mathrm{~V}$ and $-0.4 \mathrm{~V}$ vs. $\mathrm{Hg} / \mathrm{HgO}$, respectively).

Recently, a bifunctional palladium-based catalyst was produced on a carbon support with exceptionally good corrosion resistance compared with those used in commercial Pt electrodes, [9] circumventing some of the degradation problems associated with repeated cycling of bifunctional oxygen electrodes in alkaline solution. The loading of palladium on this electrode 
was only $0.5 \mathrm{mg} \mathrm{cm}^{-2}$, four times lower than a commercial $\mathrm{Pt} / \mathrm{C}$ electrode. This electrode achieved a stable oxygen evolution potential over 1,000 charge-discharge cycles, and had +0.01 and $+0.54 \mathrm{~V} v s . \mathrm{Hg} / \mathrm{HgO}$ onset potentials for oxygen reduction and evolution respectively.

This paper reports the manufacture and performance of a highly stable novel air-breathing electrode which contains a mixture of the $\mathrm{Pd} / \mathrm{C}$ catalyst materials reported previously [9] with a newly-developed low-cost oxygen catalyst based on a mixed $\mathrm{Ni} / \mathrm{Fe}$ hexacyanoferrate (referred to as the "Ni/Fe catalyst" in this publication). The performance of the catalysts was complimentary as the $\mathrm{Pd} / \mathrm{C}$ catalyst had high activity towards the ORR, and the $\mathrm{Ni} / \mathrm{Fe}$ catalyst had high activity towards the OER. The catalyst materials were first tested on a RDE, and then included in the catalyst layer of a GDE electrode to provide valuable information on catalyst performance that could be used during the scale-up process.

\section{Experimental}

\subsection{Synthesis of $\mathrm{Ni} / \mathrm{Fe}$ hexacyanoferrate catalyst (for OER)}

A $50 \mathrm{~cm}^{3}$ aqueous solution containing $0.12 \mathrm{~mol} \mathrm{dm}^{-3} \mathrm{NiSO}_{4} \cdot 6 \mathrm{H}_{2} \mathrm{O}$ and $0.03 \mathrm{~mol} \mathrm{dm}^{-3}$ $\mathrm{FeSO}_{4} .7 \mathrm{H}_{2} \mathrm{O}$ was added to a $50 \mathrm{~cm}^{3}$ solution of $0.1 \mathrm{~mol} \mathrm{dm}^{-3} \mathrm{~K}_{3}\left[\mathrm{Fe}(\mathrm{CN})_{6}\right]$ and left stirring overnight at $1200 \mathrm{rpm}$ and $20{ }^{\circ} \mathrm{C}$. The solution was centrifuged to separate the $\mathrm{Ni} / \mathrm{Fe}$ catalyst which was dried at $60^{\circ} \mathrm{C}$ for 24 hours.

\subsection{Synthesis of $\mathrm{Pd} / \mathrm{C}$ catalyst (for ORR)}

The $\mathrm{Pd} / \mathrm{C}$ catalyst was synthesized by a colloidal method, employing sulphites as complexing agents, as described elsewhere [22, 23]. The carbon support (supplied by IMERYS Graphite \& Carbon, $220 \mathrm{~m}^{2} \mathrm{~g}^{-1}$ surface area) was suspended in distilled water and stirred in an ultrasonic 
water bath at $80^{\circ} \mathrm{C}$ to form a slurry. An acidic solution containing an appropriate amount (to reach a final loading of $30 \mathrm{wt}$. \% of $\mathrm{Pd}$ on the support) of $\mathrm{Na}_{6} \mathrm{Pd}\left(\mathrm{SO}_{3}\right)_{4}$ was successively added to the slurry. The $\mathrm{Pd}$ sulphite complex solution was decomposed by adding $\mathrm{H}_{2} \mathrm{O}_{2}$ and successively increasing the $\mathrm{pH}$ to 5.5 to form colloidal $\mathrm{PdO}_{\mathrm{x}} / \mathrm{C}$. The metallic oxide was reduced in a $\mathrm{H}_{2}$ stream at room temperature $\left(23^{\circ} \mathrm{C}\right)$ to form the $30 \mathrm{wt} . \% \mathrm{Pd} / \mathrm{C}$ catalyst.

\subsection{Construction of the gas diffusion electrodes}

The gas diffusion electrode was produced using a similar method to that reported in a previous publication. ${ }^{[9]}$ A $50 \times 50 \times 0.11 \mathrm{~mm}$ piece of 25 wt. \% PTFE-treated carbon cloth (FuelCell.com), was coated with a $100 \mu \mathrm{m}$ layer of a paste containing $80 \mathrm{wt}$ \% carbon $\left(64 \mathrm{~m}^{2}\right.$ $\mathrm{g}^{-1}$, IMERYS) and 20 wt. \% PTFE (DISP 30 solution, DuPont) to form the gas diffusion layer $(\mathrm{GDL})^{[2]}$.

For the mixed-catalyst electrode, the catalyst layer was an ink made from $42 \mathrm{mg} 30 \mathrm{wt} . \% \mathrm{Pd} / \mathrm{C}$ and $125 \mathrm{mg} \mathrm{Ni} / \mathrm{Fe}$ with $25 \mathrm{mg}$ carbon, the mixture being sonicated for 15 minutes in a $5 \mathrm{wt} . \%$ Nafion $^{\circledR}$ aliphatic alcohol suspension (Sigma Aldrich), with a 3:2 weight ratio of (catalysts + carbon):Nafion. This provided a $5 \mathrm{mg} \mathrm{cm}^{-2} \mathrm{Ni} / \mathrm{Fe}$ loading and a $0.5 \mathrm{mg} \mathrm{cm}^{-2} \mathrm{Pd}$ loading. A 0.05 mm thick nickel mesh (Dexmet, 32) current collector was placed above the catalyst layer and the electrode was pressed for 2 minutes at $180{ }^{\circ} \mathrm{C}$ at $5 \mathrm{MPa}$ (Carver, model 3851 press).

As well as the mixed catalyst electrode, two electrodes were produced that contained only one of the catalysts; $5 \mathrm{mg} \mathrm{cm}^{-2} \mathrm{Ni} / \mathrm{Fe}$ or $0.5 \mathrm{mg} \mathrm{cm}^{-2} \mathrm{Pd} / \mathrm{C}$, in the same mass quantities as shown above. 


\subsection{Characterisation of the catalysts}

Scanning electron microscopy (SEM) was performed on a $0.5-30 \mathrm{kV} \mathrm{JSM} 6500 \mathrm{~F}$ thermal emission SEM. Transmission electron microscopy (TEM) was performed using a $300 \mathrm{kV}$ JEOL 3010 TEM on S147-3 copper grids coated with perforated carbon film (Agar Scientific). Infrared spectroscopy was performed on a Nicolet iS10 spectrometer (Thermo Fisher Scientific).

\subsection{Electrochemical analysis}

For the electrochemical analysis, the GDE was clamped onto a flange of a 3-electrode cell, exposing a $0.785 \mathrm{~cm}^{2}$ circular area to a $6 \mathrm{~mol} \mathrm{dm}^{-3} \mathrm{KOH}$ electrolyte. The counter electrode was a $1 \mathrm{~cm}^{2}$ platinum mesh and the reference electrode was a $\mathrm{Hg} / \mathrm{HgO}\left(1 \mathrm{~mol} \mathrm{dm}{ }^{-3} \mathrm{KOH}\right)$ electrode (Hach-Lange, - 0.115 V vs. SHE). Oxygen gas (99.999 \% purity, BOC) was circulated at atmospheric pressure via a glass tap in the back at a rate of $100 \mathrm{~cm}^{3} \mathrm{~min}^{-1}$. Cyclic voltammograms (CVs) at $1 \mathrm{mV} \mathrm{s}^{-1}$, and charge-discharge profiles at constant current, were recorded using a potentiostat (Metrohm PGSTAT 302N). The cell was fitted with a glass jacket to circulate water from a water bath at a controlled temperature $0-100{ }^{\circ} \mathrm{C}$ (Julabo, model F12$\mathrm{EH})$. The reference and counter electrodes were the same as used for the RDE experiments. A fresh piece of GDE was used for each scan or each series of charge-discharge cycles.

\section{Results and Discussion}

\subsection{Characterisation of the gas diffusion electrodes}

The SEM images in Figure 1 show the cross-sectional structure of the gas diffusion electrodes catalysed with $\mathrm{Pd} / \mathrm{C}$ and $\mathrm{Ni} / \mathrm{Fe}$ catalysts. The electrodes, produced via a hot-pressing method, were approximately $0.5 \mathrm{~mm}$ thick, and had a three-layered structure of gas diffusion layer, catalyst layer and nickel current collector. In these images, the uncut side of the electrode that had not been subject to any forces other than the original hot-pressing was presented to the 
electrode beam. The layers were mutually adherent with a dense layer of compacted powder within the catalyst layer. The total thickness was regular and consistent along the length of the electrode, although the thickness of the gas diffusion layer varied slightly owing to the irregular shape of the carbon cloth fibres, meaning that in some areas the overlaying catalyst layer is more compressed than in others.

TEM and XRD investigations of the catalyst particles revealed that the $\mathrm{Pd} / \mathrm{C}$ catalyst has a $\mathrm{Pd}$ a crystallite size of ca. $10.0 \mathrm{~nm}$, and the Pd shows a typical face centered cubic structure (fcc), as reported previously [9]. The Pd particles were well-dispersed on the carbon support (Figure 2a), and the carbon support particles had a partially graphitic structure, which is required for withstanding oxidizing potentials. Thermal gravimetric analysis confirmed the metal concentration of 30 wt. \% Pd with an estimated accuracy of $\pm 1 \%$ [9].

The Ni/Fe hexacyanoferrate particles were larger (Figure 2b), with 20-30 nm agglomerated particles. The crystalline XRD pattern (Figure 3a) can be indexed with reflections similar to $\mathrm{Ni}_{3}\left[\mathrm{Fe}(\mathrm{CN})_{6}\right]_{2}[24]$. Elemental analysis of a $100 \mu \mathrm{m}^{2}$ aggregate using SEM (Figure 3b) showed an atomic ratio of 1:1 Ni:Fe. The FTIR spectrum (Figure 3c) shows a structure similar to $\mathrm{Ni}_{3}\left[\mathrm{Fe}(\mathrm{CN})_{6}\right]_{2}$ and $\mathrm{Fe}_{3}\left[\mathrm{Fe}(\mathrm{CN})_{6}\right]_{2}$, with $\mathrm{CN}$ stretching modes at 2047 and $2165 \mathrm{~cm}^{-1}[25,26]$. The $3306 \mathrm{~cm}^{-1}$ and $1603 \mathrm{~cm}^{-1}$ peaks indicate crystallographic water, [26, 27] and C-O stretching peaks at 1120 and $1030 \mathrm{~cm}^{-1}$ suggest carbonates chemisorbed on the surface [28]. The $592 \mathrm{~cm}^{-}$ ${ }^{1}$ peak is due to Fe-CN bending [25]. The XRD, EDX and FTIR results combined suggest a hybrid structure of $\mathrm{Ni}_{3}\left[\mathrm{Fe}(\mathrm{CN})_{6}\right]_{2}$ and $\mathrm{Fe}_{3}\left[\mathrm{Fe}(\mathrm{CN})_{6}\right]_{2}$, with molecular formula $\mathrm{Ni}_{5} \mathrm{Fe}\left[\mathrm{Fe}(\mathrm{CN})_{6}\right]_{4}$. 


\subsection{Electrochemical analysis of the mixed catalyst oxygen electrode}

The gas diffusion electrodes were examined in a 3-electrode glass cell to compare the behaviour of a mixed catalyst $\mathrm{Ni} / \mathrm{Fe}+\mathrm{Pd}$ electrode with that of electrodes only containing a single catalyst. Figure 4 shows cyclic voltammetry of the electrodes containing $\mathrm{Pd}, \mathrm{Ni} / \mathrm{Fe}$ and

$\mathrm{Ni} / \mathrm{Fe}+\mathrm{Pd}$ catalysts. The behaviour of the mixed catalyst electrode is very interesting compared to the electrodes that used the catalysts separately. The curves show that for the oxygen reduction reaction, the electrode performance in terms of reduction onset potential and current density at the $\mathrm{Ni} / \mathrm{Fe}+\mathrm{Pd}$ is very similar to that of the $\mathrm{Pd}$ electrode, since $\mathrm{Pd}$ is a superior ORR catalyst to $\mathrm{Ni} / \mathrm{Fe}$ [29]. For the OER, the performance of the mixed catalyst electrode did not equal that of the $\mathrm{Ni} / \mathrm{Fe}$ catalyst. In fact, there seems to be an additive effect where the presence of both catalysts enhances the OER performance. The onset potential for the OER is the same for $\mathrm{Ni} / \mathrm{Fe}+\mathrm{Pd}$ as $\mathrm{Ni} / \mathrm{Fe}$, at $+0.33 \mathrm{~V}$ vs. $\mathrm{Hg} / \mathrm{HgO}$, but the current density is twice as high at $+0.65 \mathrm{~V}$ vs. $\mathrm{Hg} / \mathrm{HgO}$ for the $\mathrm{Ni} / \mathrm{Fe}+\mathrm{Pd}$ electrode. The current density at the $\mathrm{Ni} / \mathrm{Fe}+$ $\mathrm{Pd}$ electrode at this potential is greater than the sum of the current density at $\mathrm{Ni} / \mathrm{Fe}$ and $\mathrm{Pd}$ electrodes possibly due to a higher porous structure. Also, the reaction between $\mathrm{Pd}$ and $\mathrm{Ni} / \mathrm{Fe}$ at high positive potentials in the mixed electrode that enhances the rate of oxygen evolution also might enhance the electrical conductivity of the $\mathrm{Ni} / \mathrm{Fe}$ hexacyanoferrate (hexacyanoferrate has a low conductivity whereas Pd is metallic).

The charge-discharge profiles of the electrodes were compared at $20 \mathrm{~mA} \mathrm{~cm}{ }^{-2}$ in $6 \mathrm{~mol} \mathrm{dm}^{-3}$ $\mathrm{KOH}$ over 4 days, with 4 hours for each cycle. All of the electrodes were stable over the cycling period, but those electrodes containing the $\mathrm{Ni} / \mathrm{Fe}$ catalyst showed the best stability and performance during the OER (charging cycle). The stability of the potential during each cycle was poorer with the Pd catalysed electrode. For example, in several cycles the potential curve did not reach a level current, suggesting that some corrosion may be occurring. For the OER, 
the presence of $\mathrm{Pd}$ in the mixed $\mathrm{Ni} / \mathrm{Fe}+\mathrm{Pd}$ air electrode did not seem to adversely affect its performance compared with the electrode catalysed by Ni/Fe alone. For the ORR, the $\mathrm{Ni} / \mathrm{Fe}+\mathrm{Pd}$ electrode showed the lowest overpotentials, and the performance of the all the electrodes appeared to stabilise after 25 hours cycling.

The charge-discharge cycles in Figure 5 appeared to show the opposite behaviour to the cyclic voltammetry, as the combination of catalysts $\mathrm{Ni} / \mathrm{Fe}+\mathrm{Pd}$ improved the ORR performance more than the OER performance. Charge-discharge profiles often show different behaviour to the cyclic voltammetry, i.e. during cyclic voltammetry, the potential is only held at a certain value for a few miliseconds or seconds, whereas during charge-discharge cycling the constant current drives a strong overpotential for several hours. It may be that the OER is more sensitive to the effect of being held at high potentials for extended period of time than the ORR, particularly as most of the adverse reactions such as carbon corrosion occur at positive, rather than negative, potentials $[30,31]$.

The cyclic voltammetry was compared to voltammograms recorded in other publications in similar conditions for other gas diffusion air electrodes [32, 33, 34, 35, 36]. Figure 6 shows the data for two scans of the $\mathrm{Ni} / \mathrm{Fe}+\mathrm{Pd}$ air electrode, from the equilibrium potential (where $j=0$ ) of $+0.33 \mathrm{~V}$ vs. $\mathrm{Hg} / \mathrm{HgO}$, in the negative potential direction (ORR) and the positive direction (OER), compared with data from the literature. The peak at c.a. $+0.45 \mathrm{~V} v$ s. $\mathrm{Hg} / \mathrm{HgO}$ is caused by nickel oxidation [37] and slightly masks the onset of oxygen evolution, which begins at $+0.33 \mathrm{~V}$ vs. $\mathrm{Hg} / \mathrm{HgO}$. For the $\mathrm{OER}$, the $\mathrm{Ni} / \mathrm{Fe}+\mathrm{Pd}$ air electrode outperforms all the other air electrodes in terms of current density. For the ORR, it appears that some of the $\mathrm{Pt} / \mathrm{C}$ electrodes and perovskite electrodes reported in the literature generate a higher current density and have lower ORR onset overpotentials than the $\mathrm{Ni} / \mathrm{Fe}+\mathrm{Pd}$ air electrode, $[32,33]$ but these electrodes 
did not show such good OER current densities or onset potentials. On balance, the $\mathrm{Ni} / \mathrm{Fe}+\mathrm{Pd}$ air electrode shows the strongest bifunctional oxygen performance.

The $\mathrm{Ni} / \mathrm{Fe}+\mathrm{Pd}$ electrode was systematically cycled at different current densities to analyse its performance limits. Figures 7 and 8 show how the charge and discharge potentials at the air electrode vary with cycles of increasing current density. The electrode showed stability over a wide range of current densities, which is unusual for a carbon-based gas diffusion electrode [12]. In Figure 8, the current densities of the charge-discharge cycle were progressively increased above $200 \mathrm{~mA} \mathrm{~cm}^{-2}$ and the electrode did not show significant signs of instability in the potential until $1000 \mathrm{~mA} \mathrm{~cm}^{-2}$. The electrode was cycled up to $2000 \mathrm{~mA} \mathrm{~cm}$ then cycled at $300 \mathrm{~mA} \mathrm{~cm}^{-2}$ (Figure 6) to see if the electrode was still functional. In fact, the performance of the electrode was still quite similar to the previous cycle at $300 \mathrm{~mA} \mathrm{~cm}^{-2}$, even though it had been subjected to high current densities. The overpotentials of the OER and ORR had increased, however, and the ORR potential was unstable (see the final cycle in Figure 8).

The relationship between potential reached by the $\mathrm{Ni} / \mathrm{Fe}+\mathrm{Pd}$ electrode during charging/ discharging and the current density is plotted in Figure 9 with the same relationship shown for the Pd electrode and also for a commercial Pt/C air electrode produced by Gaskatel (using data obtained in a previous publication) [9]. It is clear that both the Pt and Pd catalysed electrodes suffered a deterioration in potential at a lower current density than the $\mathrm{Ni} / \mathrm{Fe}+\mathrm{Pd}$ electrode. At lower current density $\left(<20 \mathrm{~mA} \mathrm{~cm} \mathrm{~cm}^{-2}\right)$ the commercial $\mathrm{Pt} / \mathrm{C}$ electrode showed a better performance for the OER than the other two electrodes but this effect did not persist in a higher current density range. It was previously shown that the stability of the commercial $\mathrm{Pt} / \mathrm{C}$ in strongly alkaline $6 \mathrm{~mol} \mathrm{dm}^{-3} \mathrm{KOH}$ solution was much lower over several days cycling [9]. It should be noted that this electrode is not a bifunctional electrode and was not designed to 
operate in strong alkaline environments, so its stability was not expected to be very high. It is, however, a useful guide to compare the results of the $\mathrm{Ni} / \mathrm{Fe}+\mathrm{Pd}$ electrode catalyst at short periods of time.

Finally, the effect of thousands of multiple rapid cycles was also examined at 80 and $150 \mathrm{~mA}$ $\mathrm{cm}^{-2}$ current density. Figure 10 shows 3,000 charge-discharge cycles of 2 minutes each (the ORR and OER plateaus appear as continuous line because the cycles were so short). Cycling the electrodes many times at increasingly higher current densities is a useful technique for estimating within a short time period how the air electrode may perform after many charge discharge cycles at a lower current density with a much longer duration (i.e. several hours). The $\mathrm{Ni} / \mathrm{Fe}+\mathrm{Pd}$ air electrode appears to reach a stable potential within 1 hour, and only show a small deterioration in performance after this time. The OER and ORR overpotentials are slightly larger than would be expected at these current densities from Figure 9 but this may be a reflection of the extreme conditions (rapid charge-discharge cycling 60 times per hour) that have increased the rate of carbon and catalyst corrosion at the electrode.

\section{Conclusions}

A bifunctional oxygen electrode was successfully manufactured using a mixture of $30 \mathrm{wt} . \%$ $\mathrm{Pd}$ on carbon (0.5. $\mathrm{mg} \mathrm{cm}^{-2}$ loading) and $\mathrm{Ni} / \mathrm{Fe}$ hexacyanoferrate $\left(5 \mathrm{mg} \mathrm{cm}^{-2}\right.$ loading), on a carbon based gas-diffusion electrode showing good corrosion resistance. The mixed catalyst electrode showed lower overpotentials and higher current densities for oxygen evolution and reduction compared with the individual $\mathrm{Pd}$ and $\mathrm{Ni} / \mathrm{Fe}$ catalysts. Although the $\mathrm{Pt} / \mathrm{C}$ commercial electrode is not designed as a bifunctional electrode, the mixed catalyst electrode outperformed it over the entire current density range over short periods of time. The loading of the Pd precious metal was kept very low (four times less than the commercial electrode) to reduce the cost of 
the air electrode, with a higher loading of the low-cost $\mathrm{Ni} / \mathrm{Fe}$ catalyst being used to enhance the electrode performance.

The oxygen reduction onset potential at the $\mathrm{Ni} / \mathrm{Fe}+\mathrm{Pd}$ electrode was $-0.05 \mathrm{~V}$ vs. $\mathrm{Hg} / \mathrm{HgO}$ and the oxygen evolution onset potential was $+0.33 \mathrm{~V} v \mathrm{ss} \mathrm{Hg} / \mathrm{HgO}$, and at $20 \mathrm{~mA} \mathrm{~cm}^{-2}$ charging and discharging current the electrode achieved stable potentials at -0.14 and $+0.53 \mathrm{~V} v s$. $\mathrm{Hg} / \mathrm{HgO}$, respectively. The electrode was functional at up to $1,000 \mathrm{~mA} \mathrm{~cm}{ }^{-2}$ current density and could be cycled 3,000 times at high current density $\left(150 \mathrm{~mA} \mathrm{~cm}{ }^{-2}\right)$, without significant increases in the oxygen reduction and evolution overpotentials.

\section{Acknowledgements}

This work was enabled by an EU grant FP7 (NECOBAUT Grant agreement no. 314159). The authors thank the coordinators of symposium 10 at the $66^{\text {th }}$ Annual Meeting of the International Society of Electrochemistry for the invitation to submit this investigation, and IMERYS Graphite \& Carbon for providing the carbon materials. H.A. Figueredo-Rodríguez acknowledges the financial support from CONACYT, Mexico. 


\section{Figure captions}

Figure 1 Scanning electron microscopy images showing side view cross-sections of gasdiffusion oxygen electrode catalysed by (a) $\mathrm{Pd} / \mathrm{C}$ (b) Ni/Fe and (c) $\mathrm{Pd} / \mathrm{C}+\mathrm{Ni} / \mathrm{Fe}$ mixture.

Figure 2. Transmission electrode microscopy images of the catalysts (a) $\mathrm{Pd} / \mathrm{C}$ and (b) $\mathrm{Ni} / \mathrm{Fe}$.

Figure 3. (a) Powder XRD pattern of the Ni/Fe catalyst, (b) EDX elemental analysis of a $\mathrm{Ni} / \mathrm{Fe}$ particle aggregate and (c) FTIR spectrum of $10 \mathrm{mg}$ of $\mathrm{Ni} / \mathrm{Fe}$ catalyst powder.

Figure 4. Cyclic voltammograms of gas diffusion air electrodes at $1 \mathrm{mV} \mathrm{s}^{-1}$ in $6 \mathrm{~mol} \mathrm{dm}^{-}$ ${ }^{3} \mathrm{KOH}$, with $100 \mathrm{~mL} \mathrm{~min}{ }^{-1} \mathrm{O}_{2}$ flow into the back of the electrodes. The labels $\mathrm{Pd}, \mathrm{Ni} / \mathrm{Fe}$ and $\mathrm{Ni} / \mathrm{Fe}+\mathrm{Pd}$ denote the catalysts used.

Figure 5. Charge discharge profiles of gas diffusion air electrodes at $20 \mathrm{~mA} \mathrm{~cm}^{-2}$ in $6 \mathrm{~mol}$ $\mathrm{dm}^{-3} \mathrm{KOH}$, with $100 \mathrm{ml} \mathrm{min}^{-1} \mathrm{O}_{2}$ flow into the back of the electrodes. The labels $\mathrm{Pd}, \mathrm{Ni} / \mathrm{Fe}$ and $\mathrm{Ni} / \mathrm{Fe}+\mathrm{Pd}$ denote the catalysts used.

Figure 6. Cyclic voltammograms of the $\mathrm{Ni} / \mathrm{Fe}+\mathrm{Pd}$ gas diffusion air electrode at $1 \mathrm{mV} \mathrm{s}^{-}$ ${ }^{1}$ in $6 \mathrm{~mol} \mathrm{dm}^{-3} \mathrm{KOH}$, with $100 \mathrm{ml} \mathrm{min}^{-1} \mathrm{O}_{2}$ flow into the back of the electrodes, compared with data from gas diffusion electrodes in the literature catalysed by Ag nanoparticles (NP) [36] $\mathrm{LaMnO}_{3}$ [35] $\mathrm{LaMnO}_{3}$ (2) [34] LCCO perovskite [33], Pt/C JM (JM = Johnson Matthey) [32] Pt/C (Gaskatel GmbH) [9].

Figure 7. Charge discharge profiles of the $\mathrm{Ni} / \mathrm{Fe}+\mathrm{Pd}$ catalysed gas diffusion air electrodes at $40-200 \mathrm{~mA} \mathrm{~cm}{ }^{-2}$ current density in $6 \mathrm{~mol} \mathrm{dm}^{-3} \mathrm{KOH}$, with 100

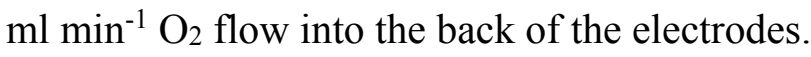

Figure 8. Charge discharge profiles of the $\mathrm{Ni} / \mathrm{Fe}+\mathrm{Pd}$ catalysed gas diffusion air electrodes at a current density of $300-2000 \mathrm{~mA} \mathrm{~cm}^{-2}$ current density in $6 \mathrm{~mol}$ $\mathrm{dm}^{-3} \mathrm{KOH}$, with $100 \mathrm{ml} \mathrm{min}^{-1} \mathrm{O}_{2}$ flow into the back of the electrodes.

Figure 9. Variation of air electrode charge and discharge potential with increasing current density for $\mathrm{Ni} / \mathrm{Fe}+\mathrm{Pd}, \mathrm{Pd}$, and commercial Pt/C air electrodes (Gaskatel).

Figure 10. Charge-discharge cycles of $\mathrm{Pd}+\mathrm{Ni} / \mathrm{Fe}$ catalysed air electrode with cycles at 80 and $150 \mathrm{~mA} \mathrm{~cm}^{-2}$ current density, over 3,000 cycles of 2 minutes each ( 1 minute charge, 1 minute discharge). 


\section{Figures}
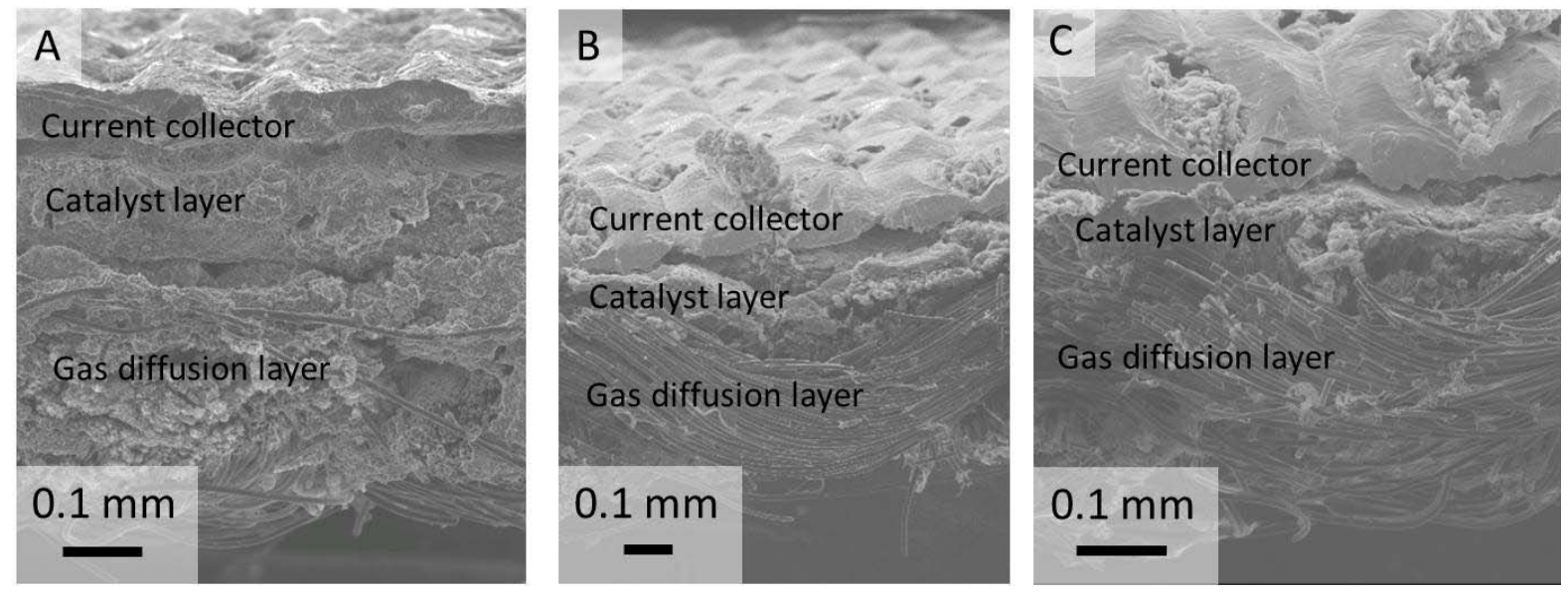

Figure 1

(a)

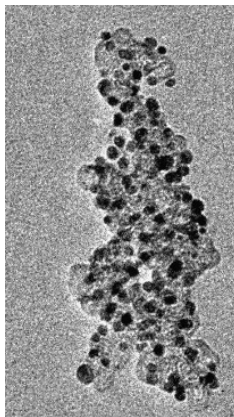

$100 \mathrm{~nm}$ (b)

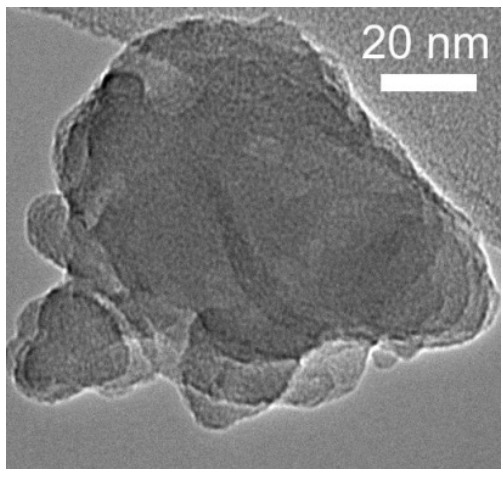

Figure 2 


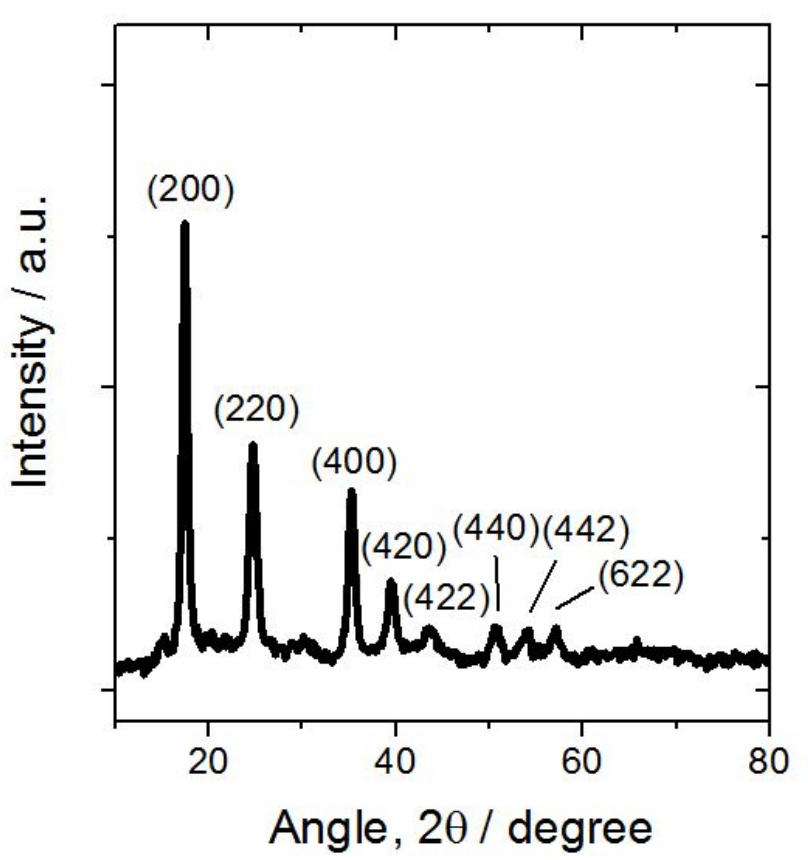

Figure 3a

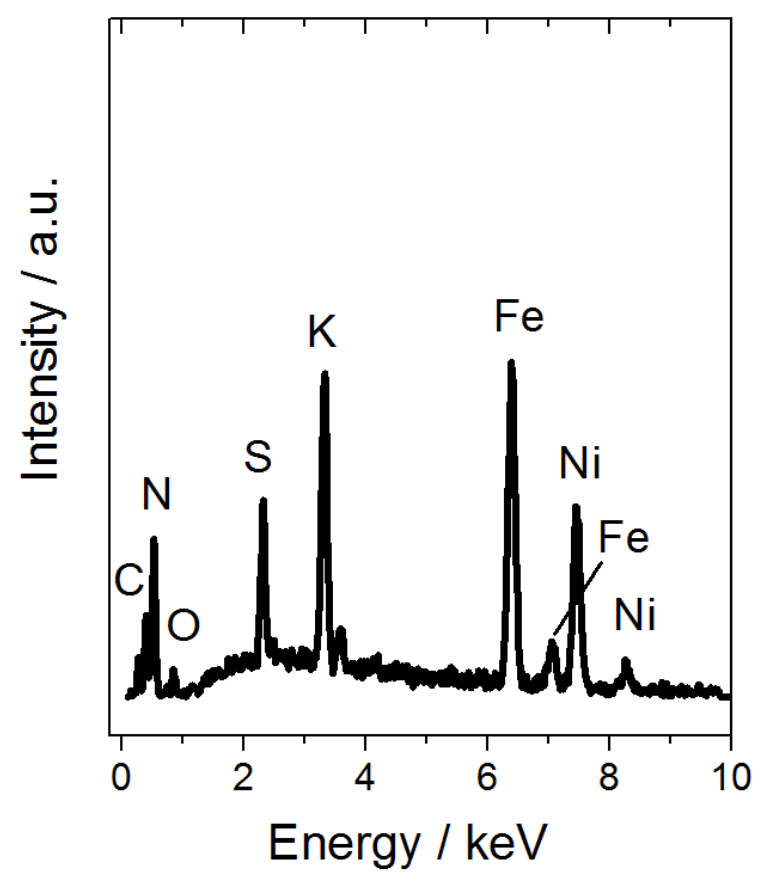

Figure 3b 


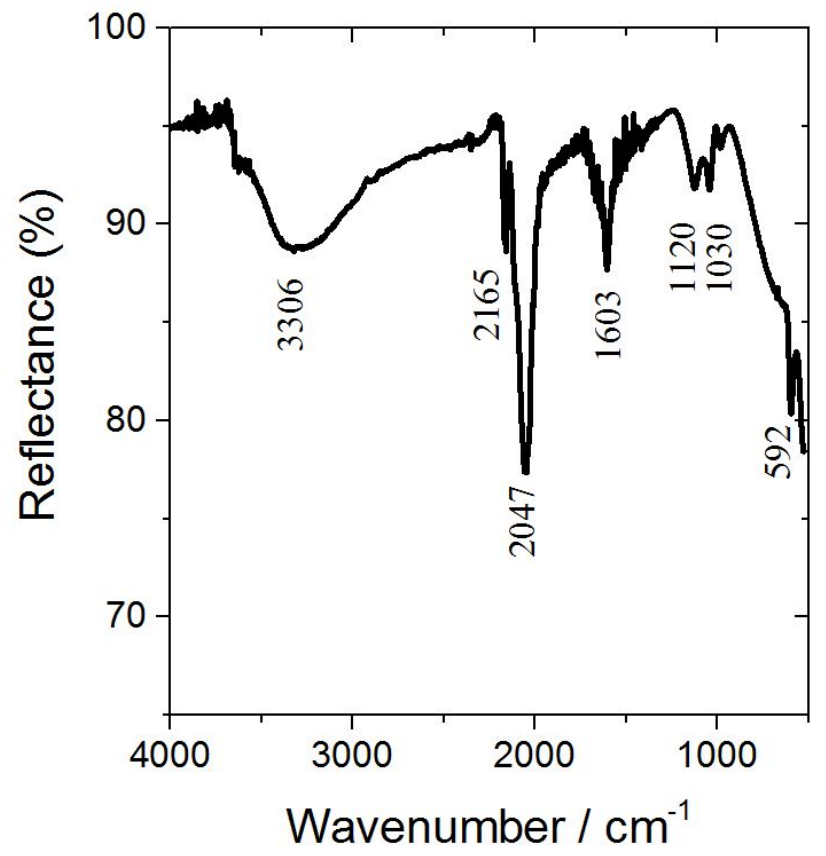

Figure 3c

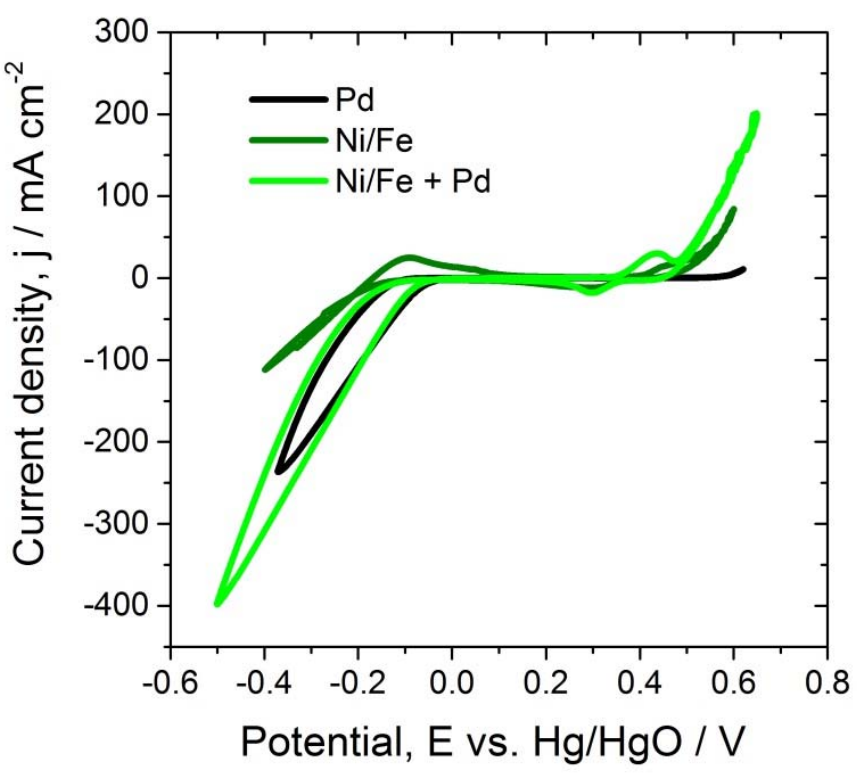

Figure 4 


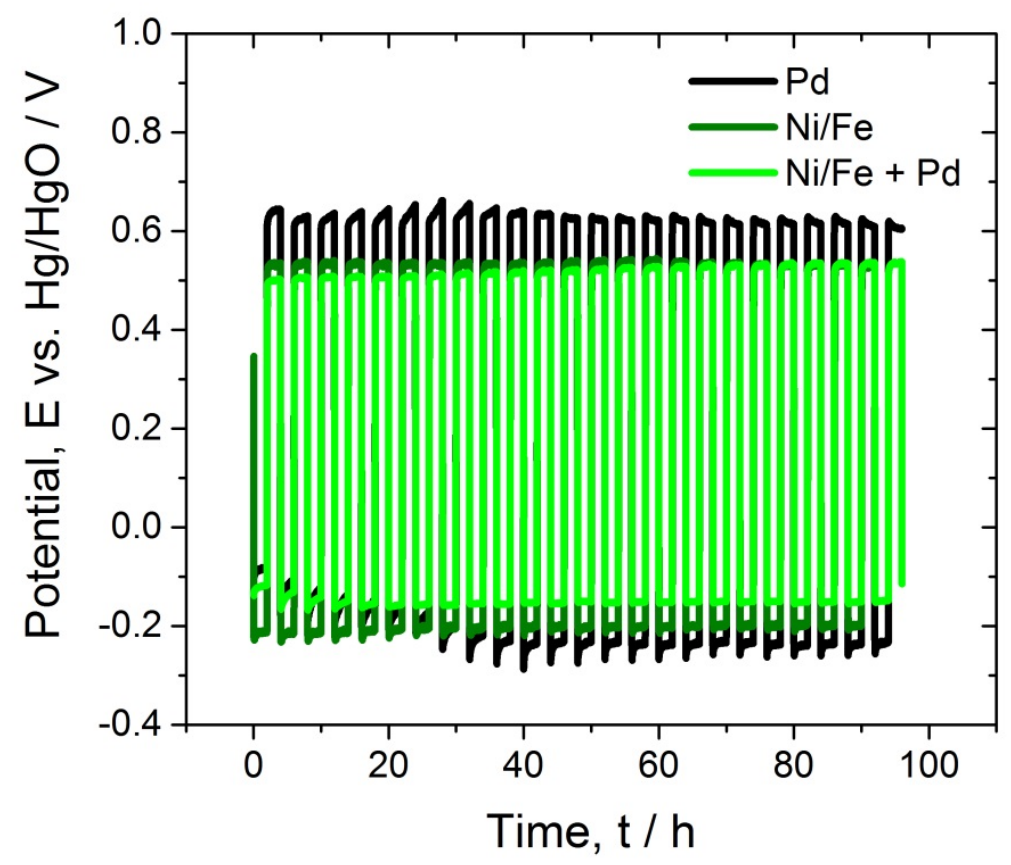

Figure 5

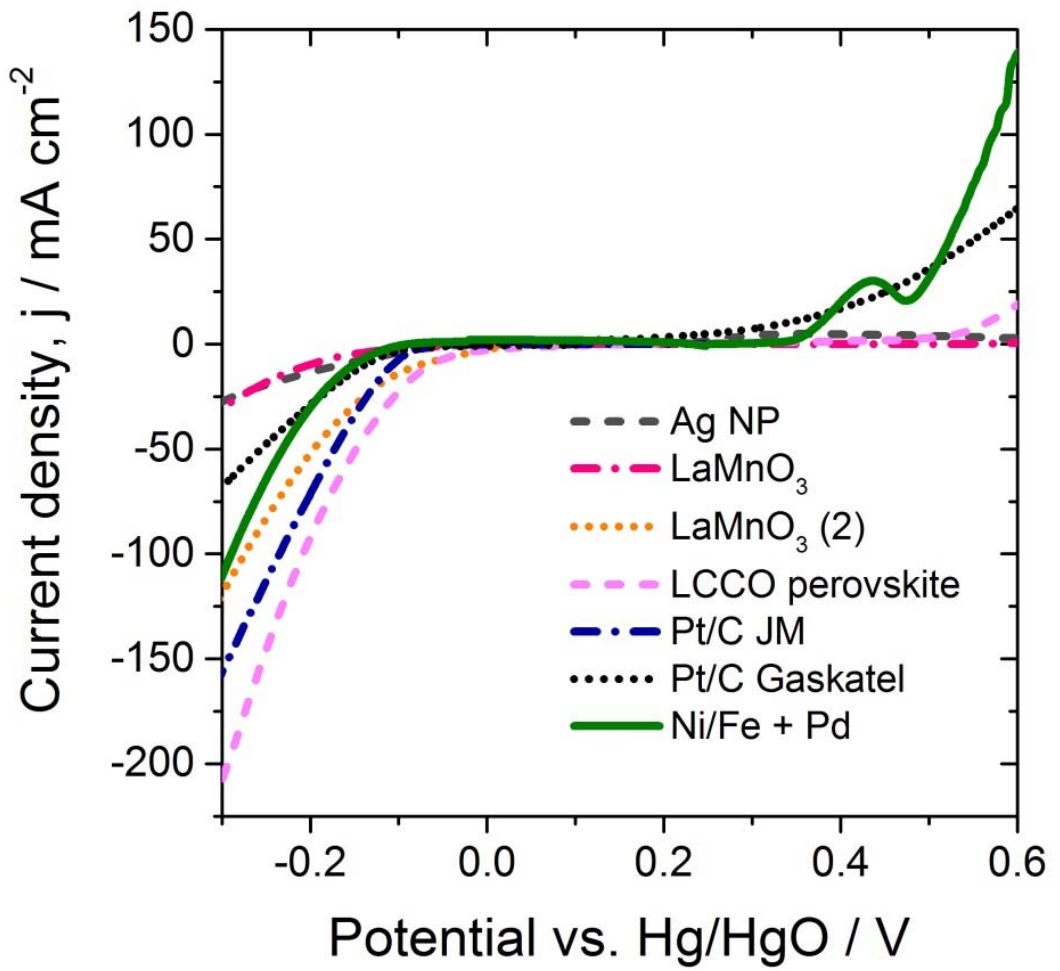

Figure 6 


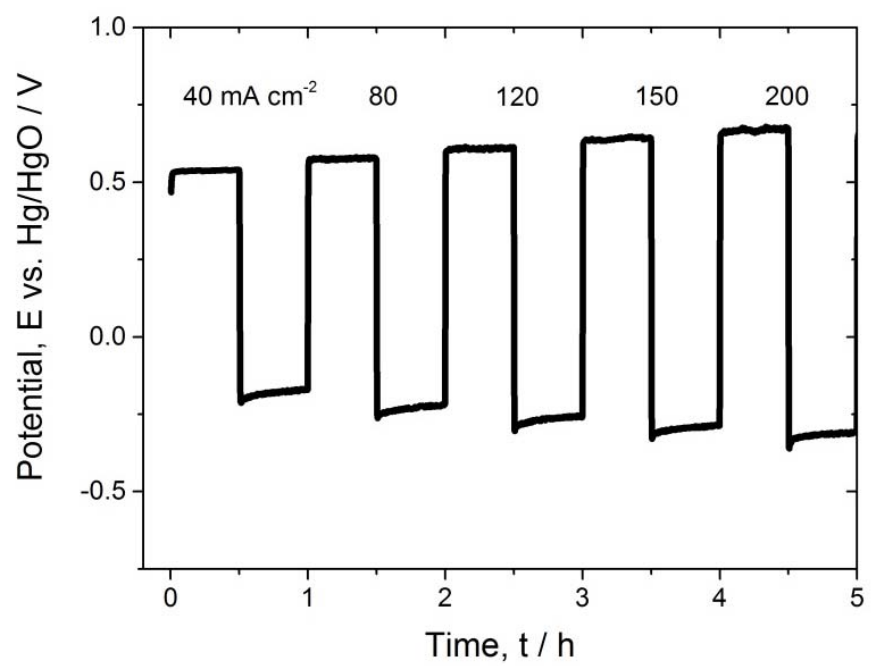

Figure 7

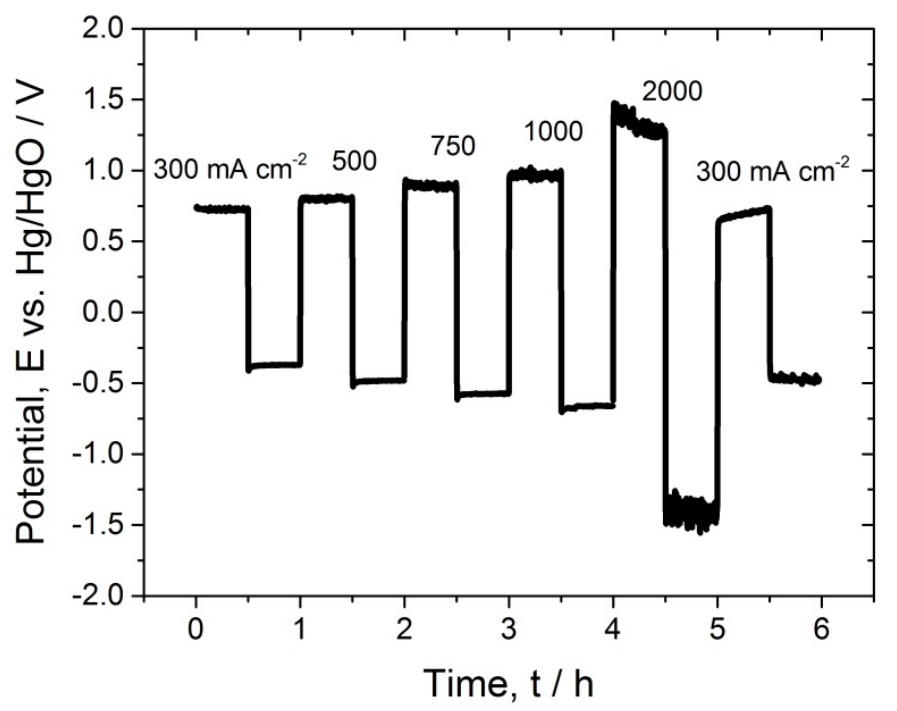

Figure 8 


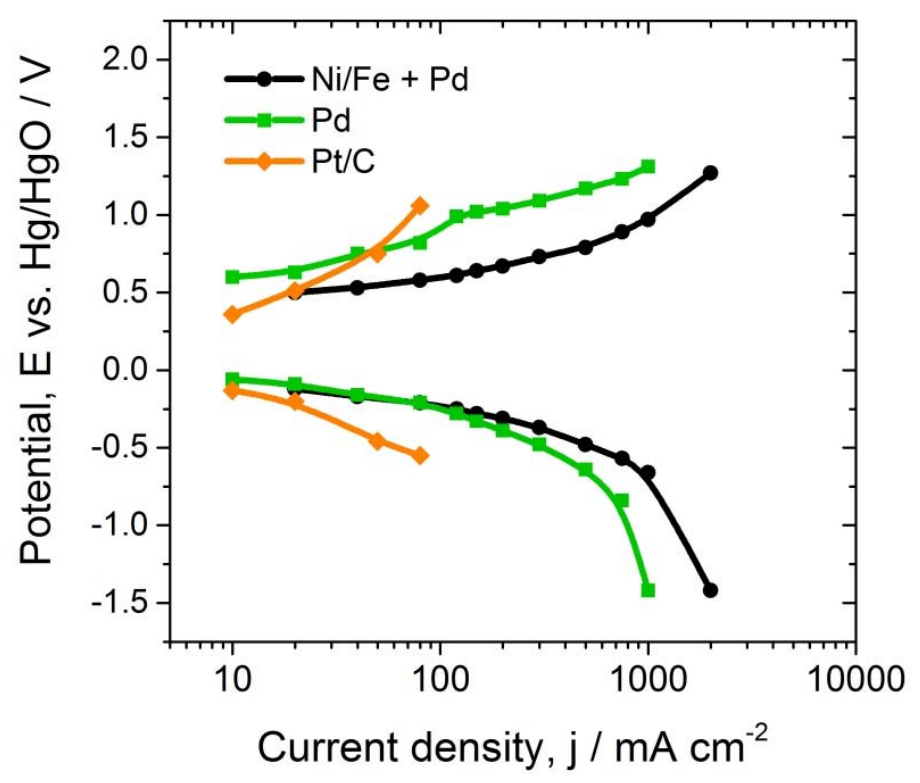

Figure 9

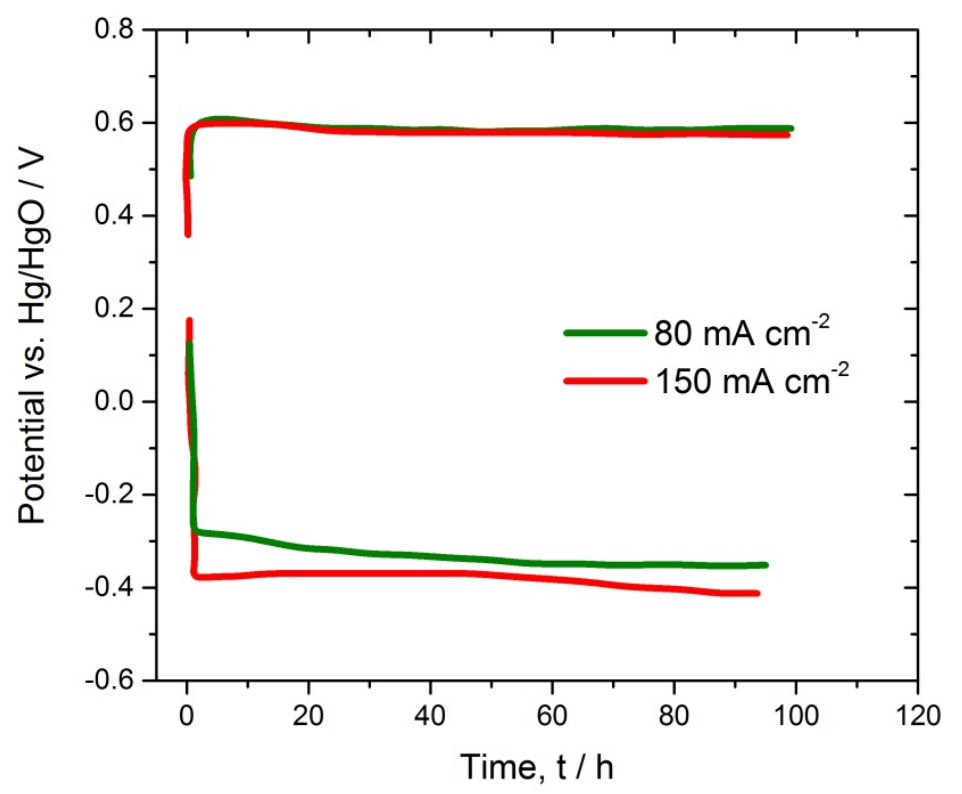

Figure 10 


\section{References}

1. Y-C Lee, P-Y Peng, W-S Chang, C-M Huang. Hierarchical meso-macroporous $\mathrm{LaMnO}_{3}$ electrode material for rechargeable zinc-air batteries. J. Taiwan Inst Chem Eng. 45 (2014) 2334.

2. Z.Q. Peng, S.A. Freunberger, Y.H. Chen, P.G. Bruce. A reversible and higher-rate Li$\mathrm{O}_{2}$ battery. Science, 337 (2012) 563.

3. K. Hayashi, K. Shima, F. Sugiyama. A mixed aqueous/aprotic sodium/air cell using a NASICON ceramic separator. J Electrochem Soc. 160 (2013) A1467.

4. X. Ren, Y. Wu. A Low-overpotential potassium-oxygen battery based on potassium superoxide. J Am Chem Soc. 135 (2013) 2923.

5. R.P. Hamlen, E.C. Jerabek, J.C. Ruzzo, E.G. Siwek. Anodes for refuelable magnesium-air batteries. J Electrochem Soc. 116 (1969) 1588.

6. N.U. Pujare, K.W. Semkow, A.F. Sammells. A calcium oxygen secondary battery. J Electrochem Soc. 135 (1988) 260.

7. D.R. Egan, C. Ponce de León, R.J.K. Wood, R.L. Jones, K.R. Stokes, F.C. Walsh. Developments in electrode materials and electrolytes for aluminium-air batteries. J. Power Sources, 236 (2013) 293-310.

8. Cohn G, Starosvetsky D, Hagiwara R, Macdonald DD, Ein-Eli Y. Silicon-air batteries. Electrochem Comm. 11 (2009) 1916.

9. R.D. McKerracher, C. Alegre, V. Baglio, A.S. Aricò, C. Ponce de León, F. Mornaghini, M. Rodlert, F.C. Walsh. A nanostructured functional $\mathrm{Pd} / \mathrm{C}$ gas-diffusion electrode for metal-air batteries. Electrochim. Acta, 174 (2015) 508-515.

10. L. Öjefors, L. Carlsson. An iron-air vehicle battery. J. Power Sources 2 (1977/78) 287-296.

11. Z.Y. Liu, J.L. Zhang, P.T. Yu, J.X. Zhang, R. Makharia, K.L. More, E.A. Stach, Transmission electron microscopy observation of corrosion behaviors of platinized carbon blacks under thermal and electrochemical conditions. J. Electrochem Soc. 157 (2010) B906-B913.

12. X. Li, D. Pletcher, A.E. Russell, F.C. Walsh, R.G.A. Wills , S.F. Gorman, S.W.T. Price, S.J. Thompson. A novel bifunctional oxygen GDE for alkaline secondary batteries. Electrochem. Comm. 34 (2013) 228-230.

13. A. Ikezawa, K. Miyazaki, T. Fukutsuka, T. Abe, J. Electrochem. Soc. 162 (2015) A1646-A1653. 
14. Z. Shuxin, H. Chenghuan, H. Kelong, X. Tu, F.H. Hongxia, Preparation of homogeneous nanoporous $\mathrm{La}_{0}{ }_{6} \mathrm{Ca}_{0}{ }_{4} \mathrm{CoO}_{3}$ for bi-functional catalysis in an alkaline electrolyte, Electrochem. Comm. 13(4) (2011) 321-324.

15. D. Pletcher, X. Li, S.W.T. Price, A.E. Russell, T. Sönmez, S. J. Thompson, Comparison of the Spinels $\mathrm{Co}_{3} \mathrm{O}_{4}$ and $\mathrm{NiCo}_{2} \mathrm{O}_{4}$ as Bifunctional Oxygen Catalysts in Alkaline Media, Electrochima Acta 188 (2016) 286-293.

16. X. Li, D. Pletcher, A.E. Russell, F.C. Walsh, RG.A. Wills, S.F. Gorman, S.W.T. Price, S.J. Thompson. A novel bifunctional oxygen GDE for alkaline secondary batteries, Electrochem Comm. 34 (2013) 228-230.

17. J. Prakash, D. A. Tryk, E. B. Yeager, Kinetic Investigations of Oxygen Reduction and Evolution Reactions on Lead Ruthenate Catalysts, J. Electrochem. Soc. 146 (1999) 4145-4151.

18. S.Velraj, J.H. Zhu. Cycle life limit of carbon-based electrodes for rechargeable metalair battery application. J. Electroanal. Chem. 736 (2015) 736.

19. M. De Koninck, P. Manseau, B. Marsan. Preparation and characterization of Nbdoped $\mathrm{TiO}_{2}$ nanoparticles used as a conductive support for bifunctional $\mathrm{CuCo}_{2} \mathrm{O}_{4}$ electrocatalyst. J. of Electroanal. Chem. 611 (2007) 67.

20. O. Kasian, T. Luk'yanenko, A. Velichenko, R. Amadelli, Electrochemical behavior of platinized Ebonex ${ }^{\circledR}$ electrodes. Int. J. Electrochem. Sci. 7 (2012) 7915-7926.

21. Y. Shimizu, H. Matsuda, N. Miura, N. Yamazoe. Bifunctional oxygen electrode using large surface area Perovskite-type oxide catalyst for rechargeable metal-air batteries. Chem. Let. 6 (1992) 1033.

22. A. Stassi, I. Gatto, V. Baglio, A.S. Aricò. Evaluation of palladium-based electrocatalyst for oxygen reduction and hydrogen oxidation in intermediate temperature polymer electrolyte fuel cells. Int. J. Hydrogen Energy, 39 (2014) 2158121587.

23. A.S. Aricò, V. Baglio, A. Di Blasi, E. Modica, P.L. Antonucci, V.J. Antonucci, Analysis of the high-temperature methanol oxidation behaviour at carbon-supported Pt-Ru catalysts. Electroanal. Chem., 557 (2003) 167-176.

24. W.A. Steen, S.W. Han, Q. Yu, R.A. Gordon, J.O. Cross, E.A. Stern, G.T. Seidler, K.M. Jeerage, D.T. Schwartz, Structure of Cathodically Deposited Nickel Hexacyanoferrate Thin Films Using XRD and EXAFS, Langmuir 18 (2002) 77147721.

25. S.N. Ghosh, Infrared spectra of the Prussian blue analogues, J. Inorg.Nucl.Chem., 36 (1974) 2465-2466.

26. I.M. Ismail, M.R. El-Sourougy, N. Abdel Moneim, H.F. Aly, Preparation, characterization, and utilization of potassium nickel hexacyanoferrate for the 
separation of cesium and cobalt from contaminated waste water, Journal of Radioanalytical and Nuclear Chemistry, 237 (1998) 97-103.

27. L. Hu, P. Zhang, Q. Chen. J. Mei, N. Yan, Room-temperature synthesis of Prussian blue analogue $\mathrm{Co}_{3}\left[\mathrm{Co}(\mathrm{CN})_{6}\right]_{2}$ porous nanostructures and their $\mathrm{CO}_{2}$ storage properties, RSC Adv. 1 (2011) 1574-1578. 10.1039/C1RA00624J

28. D.M. Gil, M. Avila, E. Reguera, S. Pagola, M.I. Gomez, R.E. Carbonio, Lead hexacyanoferrate(II) tetrahydrate: Crystal structure, FTIR spectroscopy and thermal decomposition studies, Polyhedron, 33 (2012) 450-455.

29. C. Song, J. Zhang, Electrocatalytic oxygen reduction reaction, PEM fuel cell electrocatalysts and catalyst layers, fundamentals and applications, J. Zhang (Ed.) (2008) Vol. XXI, ISBN: 978-1-84800-935-6, pp. 89-129.

30. K. Kinoshita, Electrochemical oxygen technology, Wiley, New York, 1992.

31. J.P. Meyers, R.M. Darling, Model of carbon corrosion in PEM fuel cells, J. Electrochem. Soc. 153 (2006) A1432-A1442.

32. R.D. McKerracher, C. Ponce de Léon,_R.G.A. Wills, A.A. Shah, F.C. Walsh, A review of the iron-air secondary battery for energy storage, ChemPlusChem 80 (2015) $323-335$.

33. S. Zhang, H. Zhang., S. Liu, F. Tu, W. Zhang, C. Zhao, Optimized Perovskite Electrocatalyst for bifunctional air electrode by impedance spectroscopy analysis. Int. J. Electrochem. Sci 9 (2014) 1690-1701.

34. M. Yuasa, M. Nishida, T. Kida, N. Yamazoe, K. Shimanoe. Bi-functional oxygen electrodes using $\mathrm{LaMnO}_{3} / \mathrm{LaNiO}_{3}$ for rechargeable metal-air batteries. J. Electrochem. 158 (2011) A605-A610.

35. C. Zhu, A. Nobuta, I. Makatsugawa, T. Akiyama, Solution combustion synthesis of $\mathrm{LaMO}_{3}(\mathrm{M}=\mathrm{Fe}, \mathrm{Co}, \mathrm{Mn})$ perovskite nanoparticles and the measurement of their electrocatalytic properties for air cathode Int. J. Hydrogen Energy 38 (2013) 1323813248 .

36. N. Sasikala, K. Ramya, K.S. Dhathathreyan, Bifunctional electrocatalyst for oxygen/air electrodes. Energy Conversion and Management 77 (2014) 545-549.

37. D.E. Pissinis, L.E. Sereno, J.M. Marioli, Utilization of special potential scan programs for cyclic voltammetric development of different nickel oxide-hydroxide species on Ni based electrodes, Open J. Phys. Chem. 2 (2012) 23-33. 